\title{
DESIGNING PRIORITY DATABASES FOR QMS ACCORDING TO ISO 9001: 2015 STANDARD
}

\author{
Ljiljana Z. Miletića, Aca D. Jovanović ${ }^{b}$, Filip P. Jovanovićc \\ Vesna V. Buha ${ }^{\mathrm{d}}$ \\ EDUCONS University in Sremska Kamenica, Faculty of Project and \\ Innovation Management, Belgrade, Republic of Serbia \\ a e-mail: ljmilet1@gmail.com, \\ ORCID iD: 10 http://orcid.org/0000-0003-3270-1891 \\ b e-mail: aca.jovanovic@pmc.edu.rs, \\ ORCID iD: (Thttp://orcid.org/0000-0003-2284-5875 \\ ${ }^{c}$ e-mail: filip.jovanovic@pmc.edu.rs, \\ ORCID iD: 10 http://orcid.org/0000-0002-4891-7219 \\ de-mail: vesna.buha@pmc.edu.rs, \\ ORCID iD: 『http://orcid.org/0000-0003-3239-3972
}

http://dx.doi.org/10.5937/vojtehg65-12731

FIELD: Computer Sciences, Informatics, Quality Management

ARTICLE TYPE: Review Paper

ARTICLE LANGUAGE: English

\section{Abstract}

The international ISO 9001:2015 standard for quality management system (QMS) is widely implemented in this country, especially in business organisations and in public administration. The Standard was created in 1987; it was revised and amended in 1994, 2000 and 2008, the latest amendments being of the largest scope. Compared to the previous ISO 9001:2008 standard, this standard does not require a complicated manual to be devised: instead of six, it needs no documented procedures now and only 18 prescribed reports are required in comparison with 21 in the previous version. The organisations that have already certified their standards to comply to the earlier ISO 2001:2008 standard have to adopt the new standard now, and no later than 2018. One of the greatest problems in this transition is designing the required databases necessary for the practical implementation of the new standard. The solution proposed by the authors is a general model with six priority databases: Documented information database; Measuring, control and testing equipment database; Qualified personnel database; Complaints on process output nonconformity database; Costs of process output nonconformity database and Plant and work equipment maintenance database.

Key words: Priority databases, Quality Management System, ISO 9001:2015 standard. 


\section{Introduction}

International Quality Management System (QMS) ISO 9001:2015 (ISO 9001:2015) Standard implemented in this country in business organisations and in public administration comes as a replacement of the earlier, ISO 9001:2008 standard. Hence the organisations that have already certified their standards to comply with this earlier standard now have to adopt the new standard of the quality system model, ISO 9001:2015, no later than September 2018. General preparations in the international ISO organisation commenced with the CD version (May 2013), then the DIS material was prepared for the accreditation bodies (February 2014), followed by creating the FDIS materials for the certification bodies (March 2015) and for organisational transition, as presented in the chart in Figure 1. The genuine ISO 9001: 2015 standard (ISO/TS 9002: 2016), (ISO 9000: 2015), (ISO/TC 176/SC 3ISO/NP 10015) eventually appeared in September 2016.

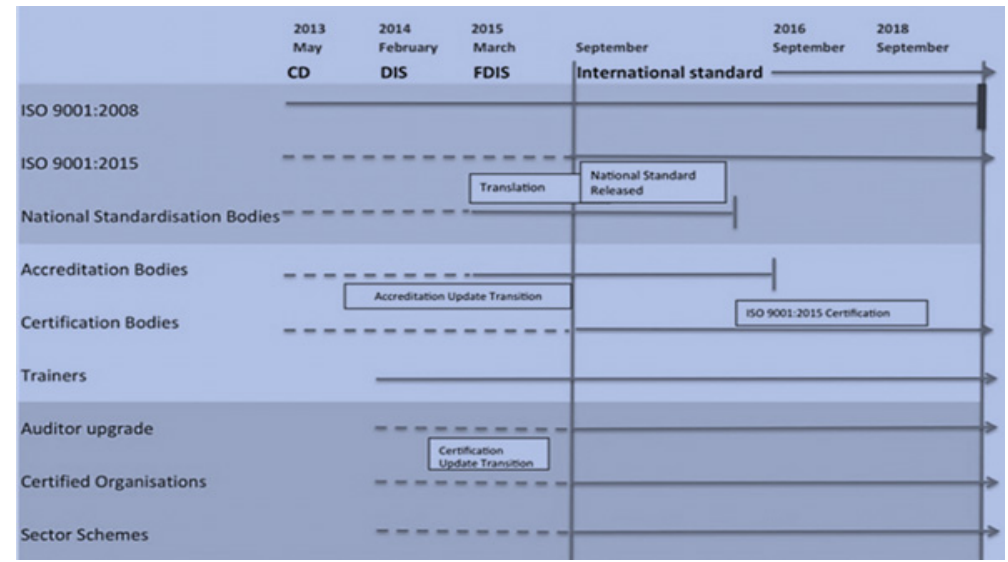

Figure 1-Official transition from ISO 9001: 2008 standard to ISO 9001: 2015

Puc. 1 - Официальный переход с ISO 9001: 2008 стандарта на ISO 9001: 2015

Слика 1 - Прописани прелаз са стандарда ISO 9001:2008 на ISO 9001:2015

The number of international standards in the integral management system increases and organisations are faced with the problem of updating. It is expected that the majority of organisations in Serbia will have successfully adopted the new standard by the given deadline (by September 2018), whereby it is necessary that our organisations should revise and amend the required 18 prescribed reports and, on the basis of these, design the databases necessary for an effective and rational 
implementation of the quality management system. The previous considerations have shown that the metal industry, on the basis of the requirements of the earlier versions of ISO standards, as of ISO 9001: 1994 and ISO 9004-1: 1994, requires the implementation of six priority databases: 1. Quality and work assurance procedures database; 2. Customer complaints and claims database; 3. Qualified personnel database; 4. Measuring, control and testing equipment database; 5. Complaints on process output nonconformity database and 6. Costs of process output nonconformity database and 6 . Plant and work equipment maintenace database (Miletić, 2001a). Under the assumption that these six databases are also priority databases for the practical implementation of new ISO 9001: 2015 standard, this paper presents a comparative analysis of a large body of information and data required to form a QMS subsystem, in compliance with the previous version of ISO 9001:2008 standard and ISO 9001: 2015 standard. Following the requirements of ISO 9001: 2015 standard, priority databases have been designed in order that an organised and systematic gathering, processing and permanent storage of necessary information and data should be provided for the QMS subsystem of the organisation.

\section{QMS Subsystem According to ISO 9001:2008}

ISO 9001: 2008 standard presented in the chart in Figure 2 (Popović, 2014), (ISO 9001: 2008), (ISO 9000: 2005) replaced an earlier adopted ISO 9001:2000 standard which, as a model of quality management subsystem (QMS), was considered to rely too much on paperwork hence increasing the risk, the uncertainty and the costs of quality management (Sroufe, Curkovic, 2008, pp.503-520). ISO 9001:2008 standard is one model of the System of business organisation subsystem that observed the key principles of quality management (Popović, Todorović, 1998) listed in ISO 9000 and ISO 9004 standards. Internationally recognised, it makes a quality framework for product and service monitoring and improvement.

Similarly to the earlier version, the implementation of ISO 9001:2008 standard is based on observing customer requirements; however, the terms are changed. Hence the term "qualifications" is replaced by the term "competence", "service" is replaced by "service provision", and "product release" is replaced by the term "product acceptance". 


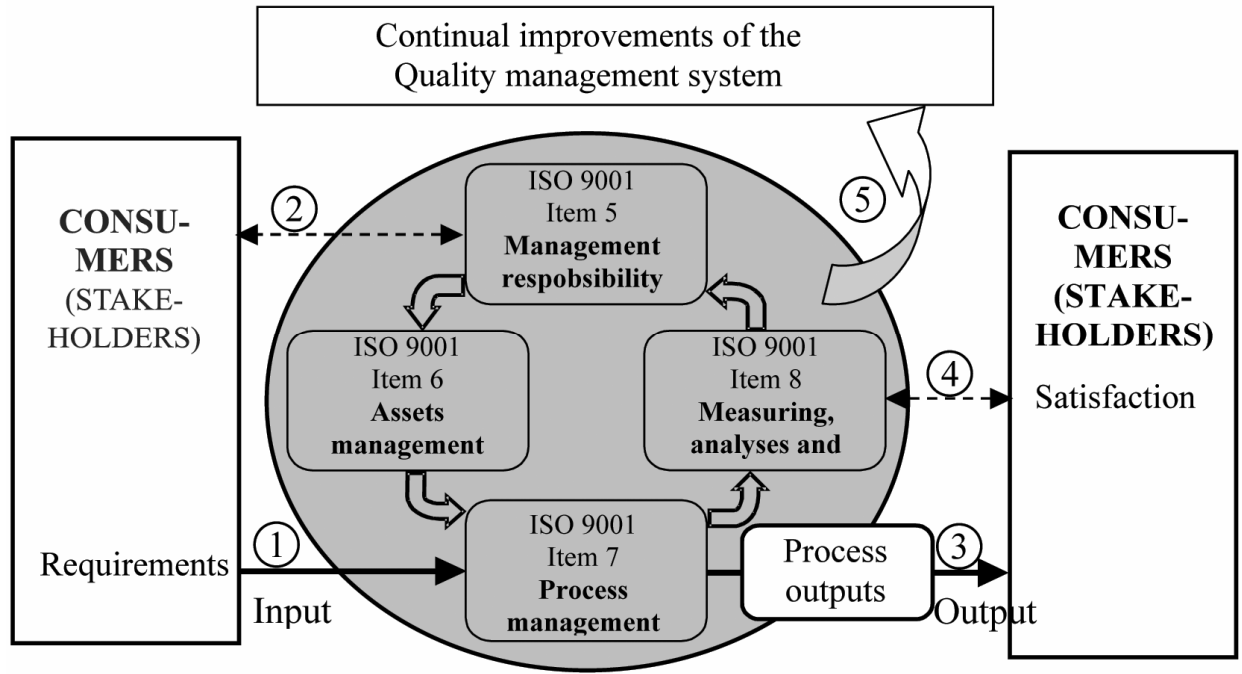

Figure 2 - Relations between the QMS subsystem and ISO 9001: 2008 standard Puc. 2 - Схема подсистем QMS u ISO 9001: 2008

Слика 2 - Шема подсистема QMS према стандарду ISO 9001:2008

ISO 9001:2008 standard requires a process-based quality management model where the effects were the efficiency and customer satisfaction improvement, improvement of quality, cost reduction as well as financial performance improvement of the business (Armistead, Machin, 1997, pp.886-898) and it has an impact on effective planning and control of necessary activities (Vanhaverbeke, Torremans, 1999, pp.41-52). The process approach encompasses all the requirements of the standard (4. Quality management system, 5. Management responsibility, 6. Resource management, 7. Process output accomplishment, 8. Testing, analyses and improvements). In terms of requirements concerning information and data on operations procedures, this standard (ISO 9001: 2008) also requires six documented actions. These are: 1. Document management procedure, 4.2.3; 2 . Record management procedure, 4.2.4; 3. Internal audit procedure, 8.2.2; 4. Defect treatment procedure, 8.3; 5. Corrective action procedure, $8.5 .2 ; 6$. Preventive action procedure, 8.5.3 as well as creation of 21 Records (1. Record on the subsystem to be submitted by the management $5.6 .1 ; 2$. Record on education, training, knowledge and experience $6.2 .2 ; 3$. Record on evidence that processes and outputs satisfy the requirements $7.1 \mathrm{~d} ; 4$. Record on input elements for design and development 7.3.2; 6. Record on design and development audit $7.3 .4 ; 7$. Record on design and development recognition 7.3.5; 
8. Record on design and development validity 7.3.6; 9. Record on design and development assessment 7.3.7; 10. Record on supplier assessment $7.4 .1 ; 11$. Record on the realisation process validity $7.5 .2 \mathrm{~d} ; 12$. Record on the process output traceability $7.5 .3 ; 13$. Record on the customer property 7.5.4; 14. Record on equipment not being calibrated due to absence of national standards 7.6a; 15 . Record on equipment non conforming to calibration $7.6 ; 16$. Record on the calibration of measuring, control or test equipment $7.6 ; 17$. Record on internal subsystem audit 8.2.2; 18. Record on the authority to control process outputs 8.2 .4 ; 19 . Record on nonconforming process outputs $8.3 ; 20$. Record on corrective action 8.5.2e and 21. Record on preventive action 8.5.3d).

\section{QMS Subsystem According to ISO 9001:2015 Standard}

The new ISO 9001:2015 standard also has a quality management subsystem (QMS) as presented in the chart in Figure 3 . This is a subsystem within the Organisation System.

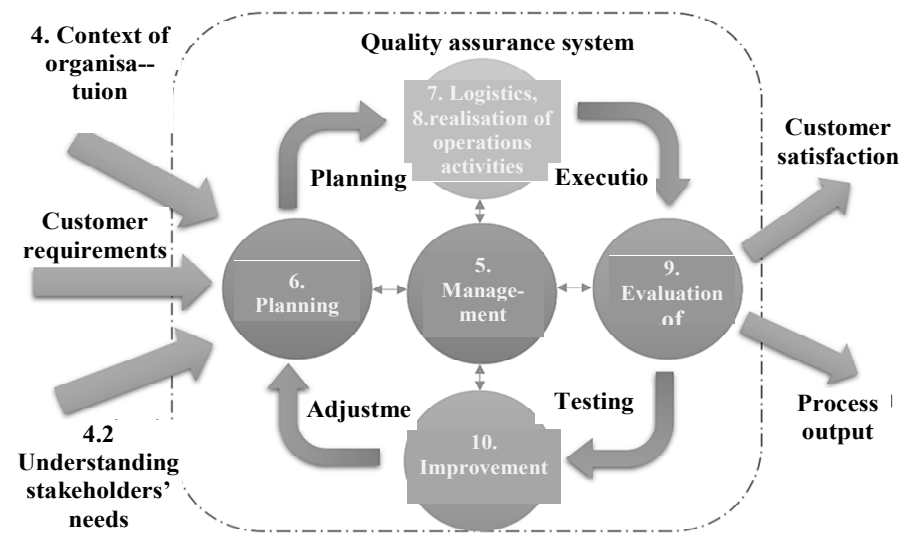

Figure 3 - Relations between the QMS subsystem and ISO 9001: 2015 standard Puc. 3 - Схема подсистем QMS u ISO 9001: 2015

Слика 3 - Шема подсистема QMS према стандарду ISO 9001:2015

Its implementation is expected to: 1 . establish the vision of a longterm development of the organisation and the process output quality policy meant to meet customer needs and requirements; 2. enhance the introduction of business planning for the purpose of: achieving business goals, preventing problem emergence and involving the interest of 
stakeholders (owners, customers, employees) while simultaneously establishing the criteria and actions for tracking the achievement of goals and assessment of the results achieved, 3. establish a clear internal allocation of competence and authority based on documented actions for the purpose of minimizing employees' errors, and create basis for factbased decision making through documented tracking of work execution and 4. improve the relationship between the owner(s)/management and the employees through fostering open communication. This standard does not require any documented procedures at the moment (ISO/TC 176/SC 3ISO 10002: 2014), (ISO/TC 176/SC 3ISO 10004: 2012), (ISO/TC 176/SC 2ISO 9004: 2009). Also altered are the requirements as regards the earlier ISO 9001:2008 standard; however, a relationship between individual standards as shown in the chart in Figure 4 can be established.

\begin{tabular}{|c|c|c|c|}
\hline No. & Database titles & ISO 9001: 2008 & ISO 9001: 2015 \\
\hline 1 & $\begin{array}{l}\text { Database for subsystem review by the } \\
\text { management }\end{array}$ & 5.6 .1 & \multirow{2}{*}{$\begin{array}{c}\text { 3. PERSONNEL } \\
\text { (KAD): } \\
9.3 .1,7.2\end{array}$} \\
\hline 2 & $\begin{array}{l}\text { Database for education, training, knowledge } \\
\text { and experience }\end{array}$ & 6.2 .2 & \\
\hline 3 & $\begin{array}{l}\text { Database with evidence of conformity } \\
\text { of processes }\end{array}$ & $7.1 d$ & \multirow{2}{*}{$\begin{array}{l}\text { 5. QUALITY } \\
\text { COSTS (TRO): } \\
8.1,8.2 .2\end{array}$} \\
\hline 4 & $\begin{array}{l}\text { Database for process output review } \\
\text { and for required actions }\end{array}$ & 7.2 .2 & \\
\hline 5 & $\begin{array}{l}\text { Database for input elements of design and } \\
\text { development }\end{array}$ & 7.3.2 & \multirow{5}{*}{$\begin{array}{l}\text { 1. DOCUMENTED } \\
\text { INFORMATION } \\
\text { (INF): } \\
8.3 .3,8.3 .4,8.3 .6\end{array}$} \\
\hline 6 & Database for design and development review & 7.3 .4 & \\
\hline 7 & $\begin{array}{l}\text { Database for design and develepment } \\
\text { verification }\end{array}$ & 7.3 .5 & \\
\hline 8 & Database for design and development validity & 7.3.6 & \\
\hline 9 & Database for design and development review & 7.3.7 & \\
\hline 10 & Database for supplier assessment & 7.4.1 & \multirow{3}{*}{$\begin{array}{l}\text { 4. COMPLAINTS } \\
\text { (REK): } \\
\text { 8.4.1, 8.4.2, 8.5.1, } \\
8.5 .2\end{array}$} \\
\hline 11 & Database for realisation process validity & 7.5.2d & \\
\hline 12 & Database for process output traceability & 7.5.3 & \\
\hline 13 & Database for customer property condition & 7.5 .4 & \multirow{2}{*}{$\begin{array}{l}\text { 6. MAINTENANCE } \\
\text { (ODR): } \\
8.5 .3,7.1 .5\end{array}$} \\
\hline 14 & $\begin{array}{l}\text { Database for uncalibrated equipment without } \\
\text { national standards }\end{array}$ & $7.6 a$ & \\
\hline 15 & $\begin{array}{l}\text { Database for equipment nonconforming to } \\
\text { calibration }\end{array}$ & 7.6 & \multirow{2}{*}{$\begin{array}{l}\text { 2. MIK } \\
\text { EQUIPMENT } \\
\text { (MIK): } \\
7.1 .5\end{array}$} \\
\hline 16 & $\begin{array}{l}\text { Database for calibrated measurement, testing } \\
\text { and control equipment }\end{array}$ & 7.6 & \\
\hline
\end{tabular}




\begin{tabular}{|c|c|c|c|}
\hline No. & Database titles & ISO 9001: 2008 & ISO 9001: 2015 \\
\hline 17 & Database for internal audit of the system & 8.2 .2 & \multirow{2}{*}{$\begin{array}{c}\text { 3. PERSONNEL } \\
\text { (KAD): } \\
9.3 .1,7.2\end{array}$} \\
\hline 18 & Database for process output auditor authority & 8.2 .4 & \\
\hline 19 & Database for process output nonconformity & 8.3 & \multirow{3}{*}{$\begin{array}{l}\text { 4. COMPLAINTS } \\
\text { (REK): } \\
8.4 .1,8.4 .2,8.5 .1 \\
8.5 .2\end{array}$} \\
\hline 20 & Database for corrective actions & 8.5.2e & \\
\hline 21 & Baza podataka za preventivne akcije & 8.5.3d & \\
\hline
\end{tabular}

Figure 4 - Overview of the priority databases according to ISO 9001:2015

Puc. 4 - Обзор приоритетных баз данных в соответствии с ISO 9001: 2015

Слика 4 - Преглед приоритетних база података према ISO 9001:2015

The new ISO 9001:2015 standard now requires the following 18 records to be kept: 1 . Record on the quality policy $5.2 ; 2$. Record on the quality objectives $6.2 ; 3$. Record on the results of the audit conducted by the management $9.3 ; 4$. Record on education, training and experience 7.2f; 5 . Record on the scope of trust that the planned processes have been accomplished 8.1c; 6. Record on the results of the preview of requirements for process outputs $8.3 .3 ; 7$. Record on the information describing the provider valuation results 8.4 .2 ; 8 . Record on the documented information for external suppliers 8.4.3; 9. Record on documented information on external suppliers' characteristics 8.4.3; 10. Record on the unique identification of the origins of process outputs 7.5.3; 11. Record on customer's property that is lost, damaged or unsuitable for use $7.5 .4 ; 12$. Record on the results of change preview and employees that approve of change $8.5 .6 ; 13$. Record on the conformity of monitoring and control devices $7.1 .4 ; 14$. Record on the programme implementation and audit results $9.2 \mathrm{e} ; 15$. Record on the authorised employees who accept the outputs of processes for customers 8.7; 16. Record on the nature of nonconformity with subsequently undertaken actions $8.8 ; 17$. Record on the nature of nonconformity of subsequently undertaken corrective actions 10.2 and 18. Record on the results of monitoring and audit (measuring, testing, control) 9.1.1.

\section{Priority Databases According to ISO 9001: 2015}

In order that a company successfully release and launch new products, it is necessary that it should understand and correctly meet the requirements of its customers, of the market and of its competition, as well 
as manage the product life cycle and integrate people, data, processes and business systems (Day, 1981, pp.102-124). As an intellectual product, software is a significant investment that has to be justified in terms that it satisfies the user's needs at an expected level (Đorđević, 2017, pp.102124 ), which is accomplished in practice by using various models (Pavlović, Karović, 2015, pp.144-149).

The integrated database model, according to ISO 9001: standard model, enables retrieving and using data and information essential for quality achievement throughout all the phases of the product life cycle (Chang, Mills, 2015) as well as an effective and rational management in the organisational quality subsystem. The new standard can be expected to require maintenance of a number of necessary databases. However, it has been proven that, to satisfy the requirements of the subsystem of quality for quality management in business organisations it suffices to start from the following six established priority Databases: 1. Documented information database (INF); 2. Measuring, control and testing equipment database (MIK) (Popović, 2002), (Miletić, 2001b) 3. Qualified personnel database (KAD); 4. Complaints on process output nonconformity database (REK) (Miletich, Richkova, 2010, pp.8-10), (Popović, Todorović, 2000); 5. Costs of process output nonconformity database (TRO) (Miletić, 2001c) and 6. Plant and work equipment maintenace database (ODR) (Popović, 1993). Figure 5 presents the requirements of the standard concerning the priority databases.

Quality management is in the area of system management where a set of instantaneous actions or actions conducted during a space of time affects the system with the aim to accomplish the objectives of the system, namely, of management. Management involves the tasks of defining the method of management out of a set of admissible managerial actions as well as conducting managerial actions. The method of management is defined using either exact methods or in an empirical/intuitive manner. The former procedure requires the system model, the management goal, the management criterion and a defined set of applicable managerial actions, with variable values (of input, management, state and output) in order that accurate and reliable results be obtained. In the latter case, defining the method of management is based on experience, good practice, behaviour of other similar systems, intuition of people responsible for defining the method of management as well as other methods that cannot be measured, the result, of course, being less accurate and less reliable outputs. Figure 6 presents an example of the „Database“window. 


\section{Documented information database (INF)}

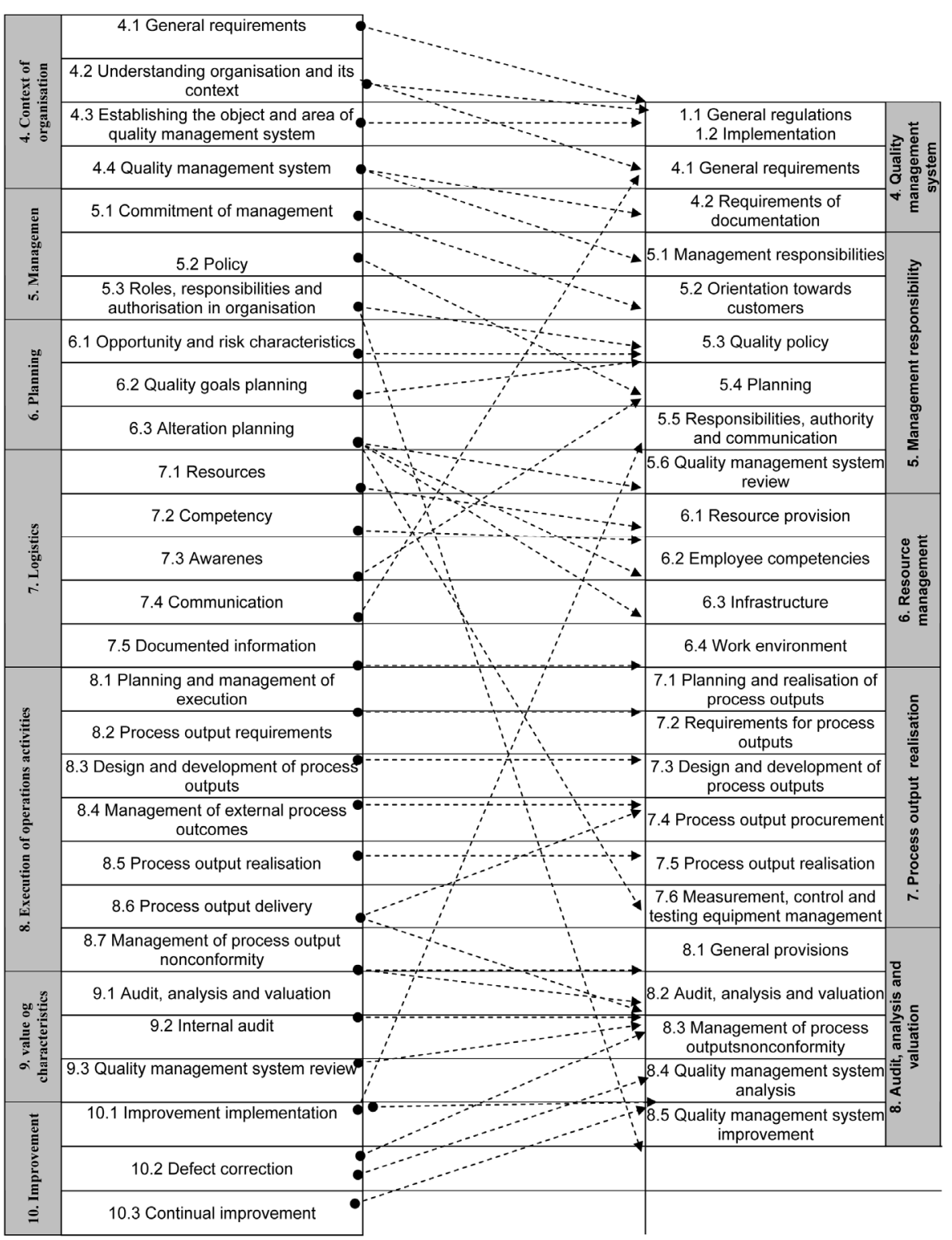

Figure 5-Overview of the prescribed a requirementsccording to ISO 9001: 2015 and ISO 9001: 2008

Puc. 5 - Обзор установленных требований, в соответствии с ISO 9001: 2015 u ISO 9001: 2008

Слика 5 - Преглед прописаних захтева према ISO 9001:2015 и ISO 9001:2008 
The first priority Process database (documented information, INF), according to the ISO 9001:2015 standard requirements 8.3.3, 8.3.4 and 8.3.6 includes: a manual, process maps, process flow diagrams and/or process descriptions, procedures, instructions for work or for testing, organisational schemes, job descriptions, quality plans and measurement, testing and control methods, plans of business operations, audit, training, internal audit and similar information.

This database makes it possible to describe the quality management system of the organisation, to provide information to related organisational parts to ensure a better understanding of their relationships, to help the employees understand their role in the organisation and to create a clear, efficient work framework, establish a basis for order and harmony in the organization, ensure compatibility in work based on documented information as well as to ensure documented bases for Quality management system verification.

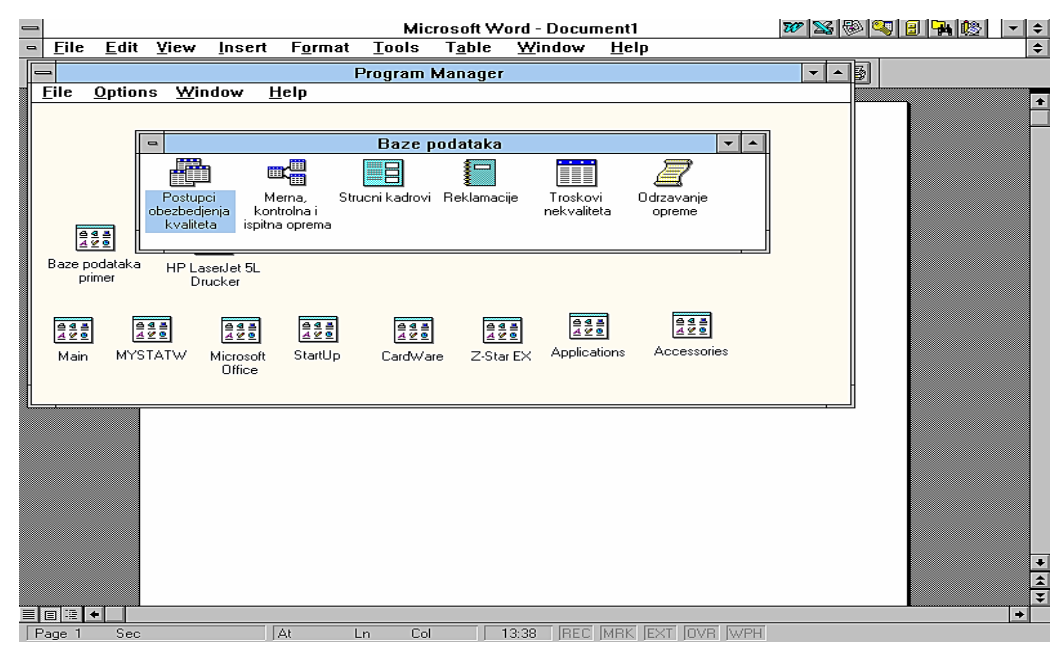

Figure 6 - "Program Manager" window with the window „Databases" Puc. 6 - Окно "Program Manager" с окном "Базы данных"

Слика 6 - Прозор „Program Manager” са прозором „Базе података”

The starting point is the "Main Menu" and the List of procedures field (List of procedures, Preview of the quality assurance procedures records, Preview of the work procedures records, Entry of a new quality assurance procedure, Entry of a new work procedure) whereby the choice of equipment enables: a) search of already entered assurance procedures, b) search of already recorded work procedures, c) entry of a new assurance procedure or work procedure, d) recording a new assurance 
procedure or work procedure, e) assignments regarding an assurance procedure or a work procedure and f) final activation.

a) The search of already filed procedures is effected by: 1 . Groups of procedures (U1, U2, U3, M, R1, R2, N, P, T, K1, K2, K3, I, Š, A, S and O) and 2. Procedures (e.g., from group N: N1 Selection of eligible supplier procedure, N2 Procedure of data collection on suppliers, N3 Selection of eligible supplier procedure, N4 Procedure of preparing a contract on material procurement, N5 Procedure of complaining of nonconformity of the materials, N6 Acceptance of procured material procedure, N7 Procedure of recording procured materials).

b) The search of already filed work procedures is carried out by Organisational units (Research of market demand (IST), Management of organisaton (RUK), Process output quality management and assurance (UPR), Process output design and development (PRJ), Planning and preparation of execution (PLA), Personnel training and record keeping $(\mathrm{OBU})$, Material and equipment procurement and storage (NAB), Technology realisation (REA), Process output quality control (KON), Process output sales or distribution and storage (PRO), Process output installation (UGR) and Process output servicing or maintenance (SER). Figure 7 presents the window Search in selection of the $\mathrm{N}$ group of procedures and the provision procedure N3 Selection of eligible supplier procedure.

c) Entry of a new provision procedure or work procedure, by procedures or by organisational units, involves filling-in the record cards, namely, "Product or service provision procedure record" and "Work procedure record" forms that include the following data: Number of procedure, Identification of procedure, Work identification, Identification of operation, Identification number, Title of procedure, Objective of procedure, Responsibility record with a procedure sample, Controller, Manager, Archivist, Director, This procedure is conducted following, This procedure affects the procedures, Responsibility for this procedure is delegated to, Authorised person for procedure execution, Authorised person for interpretation and alterations in the procedure, This procedure is designed by, Date, Surname and name, Signature sign, This procedure is approved by, Date, Surname and name, Signature sign, Responsibility record with a procedure sample, Controller, Manager, Archivist, Director.

d) Record of a new procedure of the (product or service) provision procedure or a work procedure contains the following data: Record of responsibilities of the Quality assurance controller with a sample of the procedure that is kept in his/her work documentation, Record of responsibilities of the Operations assurance manager with a sample of the procedure that is kept in his/her work documentation, Record of 
responsibilities of the Archivist in the design department with a sample of the procedure that is kept in his/her Quality management manual, Record of responsibilities of the Quality department director with a sample of the procedure that is kept in his/her Quality management manual, Date of assuming the responsibility, Number of issue, Copy number, Surname and name, Job position, Signature sign.

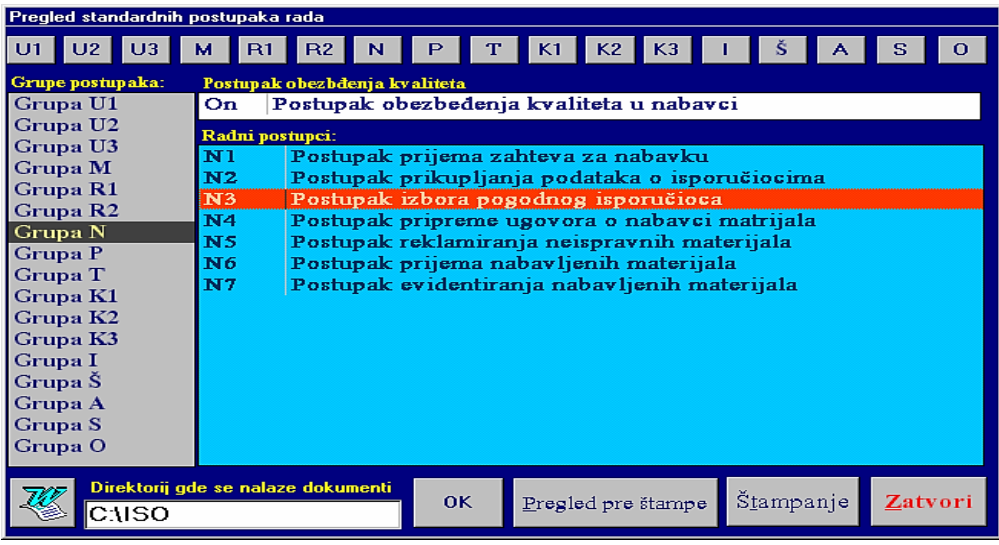

Figure 7 - Example of the window "searching" according to the group of processes and the providing procedure

Puc. 7 - Пример окна "Поиск" по группе процессов и процедуры обеспечения Слика 7 - Пример прозора „Претраживања” по групи поступака и поступцима обезбеђења

e) Assignment of the assurance procedure or work procedure by procedures or organisational units contains the following data: Quality assurance controller, Organisational sector manager, Archivist, Quality department director, Date of assuming the responsibility, Number of issue, Copy number, Surname and name, Job position, Signature sign.

f) Final activation (Print preview and Printing).

\section{Measuring, Control and Testing Equipment Database (MIK)}

The second priority database, Measuring, control and testing equipment database (MIK), according to 7.1.5 requirement of ISO 9001: 2015 standard includes planned, procured, metrologically approved, metrologically verified, recorded, distributed and maintained measurement, testing and control equipment. It starts from the "Main Menu"window and 
the "Select type of equipment (Measurement equipment, Testing equipment, Control equipment)" field; this selection of type of equipment enables: a) search of already filed data, b) entry of data about new equipment, c) position of the metrological verification of the recorded equipment, d) preview of recorded equipment and e) final activation (Print preview and Printing).

a) The search of already entered data is done by: 1. identification number, 2. inventory number, 3 . standard name of equipment, 4. workshop in which the equipment is to be used, 5. process output or 6. part of the process output for which the equipment is used, 7. method of processing or 8 . installation in which the equipment is used as well as at 9 . processing or installation line in which the equipment is used.

b) Entry of new data about new equipment involves filling in the forms: "Measurement equipment record", "Control equipment record" and "Testing equipment record", where the following is recorded: General data, Data on metrological verification, Data on adjustments, Data on repairs, in such a manner that one piece of the existing and one piece of the newly procured equipment is entered in each of the records. General data include the following data: registration (Registry book, Sequence number, Identification number, Inventory number, Number of pieces, Factory, Process output, Part, Operation, Line), Names (Standard name, Manufacturer's name, Manufacturer, Type, Model, Factory number, Year of manufacture, Accessory equipment, Instructions), characteristics (Name scope, Least value, Inaccuracy, Uncertainty) and metrological comparison (Standard, Periodicity). Data on metrological verification contain the following: Date of verification, Verified by the laboratory, Following date, Verification result, Seal and Signature signs. Data on adjustments include the following: Date, Adjustment result, Seal and Signature signs. Data on repairs include the following: Date, Repair result, Seal and Signature signs. Figure 8 shows a window with an example of the measuring equipment record for the Sliding calliper, identification number 1001. Figure 9 presents a window with an example of testing equipment for a Spectrometer, identification number 2881501. Figure 10 shows a window with an example of the record of control equipment for Control fork $71 * 30$ $(-0.1)$, marked with number 13 .

c) The position of the metrological verification of recorded equipment includes the following data: metrological verification (callibration, gauging, adjustment), repair and inspection of equipment. Equipment callibration contains the following data: issuing an order for callibration and verifying the state of callibration. Issuing the order for callibration involves a certain 
authorised laboratory, following an entry of data into the "Order for metrological verification of equipment" form in order to obtain legalisation, i.e., get a licence for work and implementation in industry, with verifications (date, name of laboratory, next date of inspection, verification result, Seal and Signature of the person responsible signs).

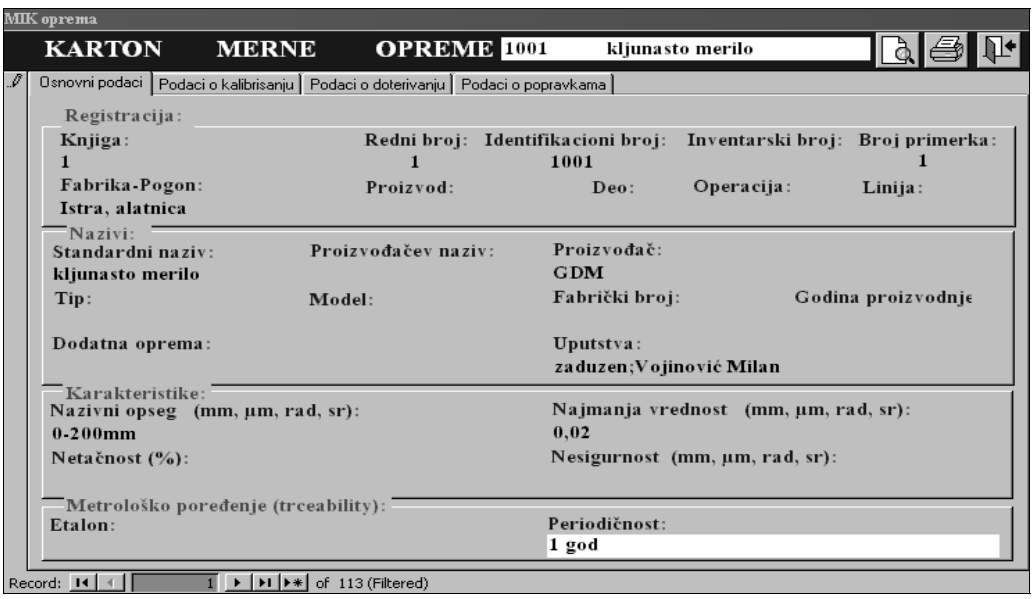

Figure 8 - Example of the window "Measuring equipment card“ Puc. 8 - Пример окна " Журнал измерительного оборудования" Слика 8 - Пример прозора „Картон мерне опреме”

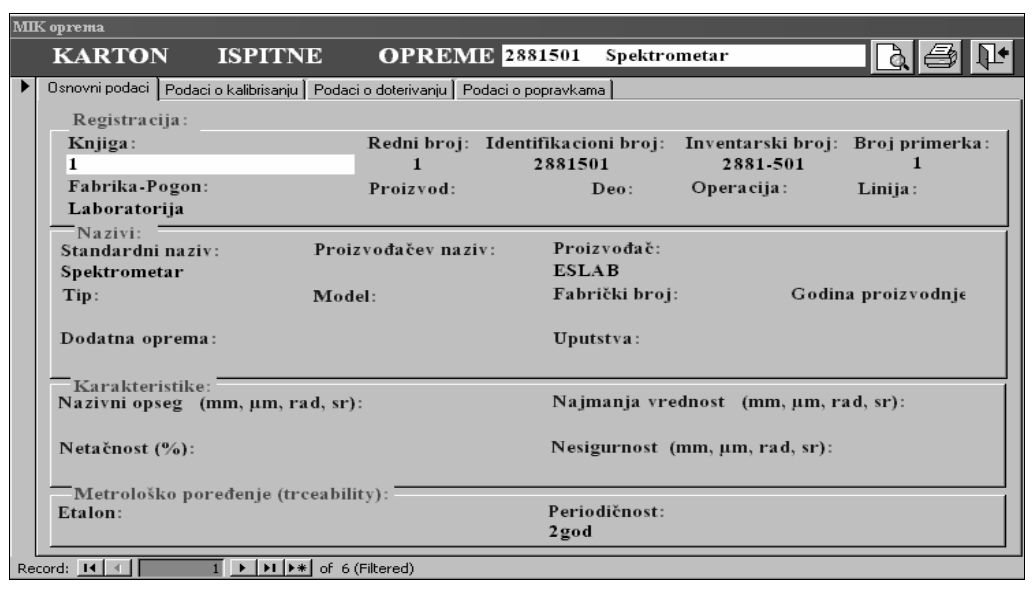

Figure 9 - Example of the window „Testing equipment card“

Puс. 9 - Пример окна "Журнал испытательного оборудования" Слика 9 - Пример прозора „Картон испитне опреме” 
The establishment of the state of the metrological verification of equipment enables a check of the date or the next date of verification in order that it should be determined whether a given piece of equipment is allowed to be used, or when the said piece should undergo the next metrological verification (Date, Laboratory, Next date, Verification result, Signature sign and Verified). Adjustment includes the following data: Date, Adjustment result, Seal and Adjustment expert signature signs). Repair includes the following data: Date, Repair result, Signs for seal and signature of the person who did the repair.

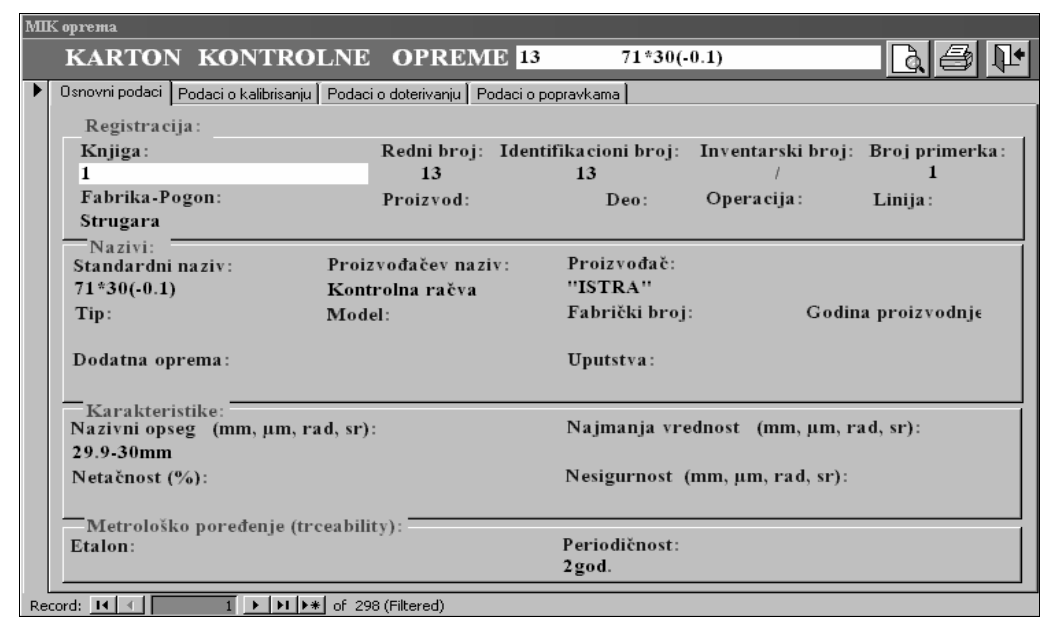

Figure 10 - Example of the window "Control equipment card"

Puc. 10 - Пример окна "Журнал контрольного оборудования"

Слика 10 - Пример прозора „Картон контролне опреме”

d) The inspection of recorded equipment includes the following data: inspection of the measuring equipment for metrological verification for the next month, the current and the next dates.

e) Final activation (Pre-print preview and Printing).

\section{Qualified Personnel Database (KAD)}

The third priority database - Qualified personnel database (KAD), according to requirements 9.3.1 and 7.3 of ISO 9001: 2015 standard, includes planned and employed professionals in the organisation. It starts from the windows "Main Menu" and the "General data" field (Personal data, job position data), Data on the employee's qualifications, Results of 
the employee over the probation period (of work), Data on the employee's training, Data on the employee's experience and Data on the employee's motivation; this choice of the type of data enables: a) search of the already filed qualified personnel, b) entry of data on new qualified personnel, c) preview of the qualified personnel file, d) preview of the general data related to qualified personnel and e) final activation.

a) The search of the already filed qualified personnel is carried out by: 1. general data (Personal data, Data on the job position/workplace), 2. data records on the employee's results during the probation period, 3 . data records on the employee's education, 4. data records on the employee's experience and 5. data records on the employee's motivation at his/her workplace.

b) Data entry on new personnel includes recording in the form: "Qualified employee record" where the following is filled in: 1. Personal data (Surname, father's name, (maiden name) and the first name, Day, month and year of birth, Place and county of birth, Unique master citizen number, Identification card and passport number, Residence address, Apartment, Home phone number), 1. Workplace data (Organisational unit, Workplace number, Workplace name, Workplace complexity coefficient, Type of employment, Location, Workplace phone number), 3. Records on the employee's performance during the probation period (Type of probation work, Name of workplace, Workplace number, Length of probation period, Evaluation grade on probation), 4. Data records on the employee's education (Type of education, Degree of education, Course route or profession, Course profile, Internal title, Length of education, Has a diploma of), 5. Data records on the employee's work experience (Type of work experience, Experience in profession, Experience in academic rank, Experience in professional rank, Experience in the course route, Experience in profile, Period of experience) and 6. Data records on the employee's motivation at his/her workplace (Type of motivation, Level of motivation, Degree of motivation).

c) The preview of the personnel database is conducted on: General data, Records of performance during the probation work period, Data records on the employee's education, Data records on the employee's work experience and Data records on the employee's motivation at his/her workplace.

d) The preview of general data is conducted on: Personal data and Workplace data.

e) Final activation (Print preview and Printing). 


\section{Complaints on Process Outputs Nonconformity Database (REK)}

The fourth priority database - Complaints on process outputs nonconformity database (REK), according to requirements 8.4.1, 8.4.2, 8.5.1 and 8.5.2 of ISO 9001: 2015 standard, includes complaints on nonconformity of own and others' process outputs (semi-products, products, documentation or services). It starts from the window "Main Menu" and the "Sales programme" field (Code of process output, Name of process output, Unit of measure and single cost of process output) and filing these data on the process output that was complained about enables: a) search of complaints on nonconformity, b) notification of a complaint, c) processing a complaint, d) resolving a complaint, e) preview of resolved complaints and f) final activation.

a) The search of sales programme is conducted by: 1 . Purpose of complaint (Identification of complaint, Process output consumers, Contract, Dispatch note, Name of process output, Structure, Part and Material of process output, Number of nonconforming and Mass of process outputs, Description of a complaint, Date of a complaint, Date and Name of person making a complaint and Claimant signature sign), 2. Identification of a complaint (Identification number, Level 1-5), 3. Process outputs (Code, Name, Unit of measure, Price of process output), 4. Resolving a complaint (Identification of a complaint, Factory, Organisational unit, Process output, Design, Workplace, Material of process output, Number of nonconforming, Consumed mass, Wasted mass, Description of a complaint, Date of a complaint, Date, Name and Signature of person making a complaint and person entering a complaint, as well as Costs of a complaint), 5. First identification (ID 1A, ID 11, Name 1), Second identification (ID 2A, ID 12, ID 22, Name 2), Third identification (ID 3A, ID 13, ID 23, ID 33, Name 3) and Fourth identification (ID 4A, ID 1, ID 2, ID 3, ID 4, Name 4). Figure 11 presents a window with an example of nonconformities. 


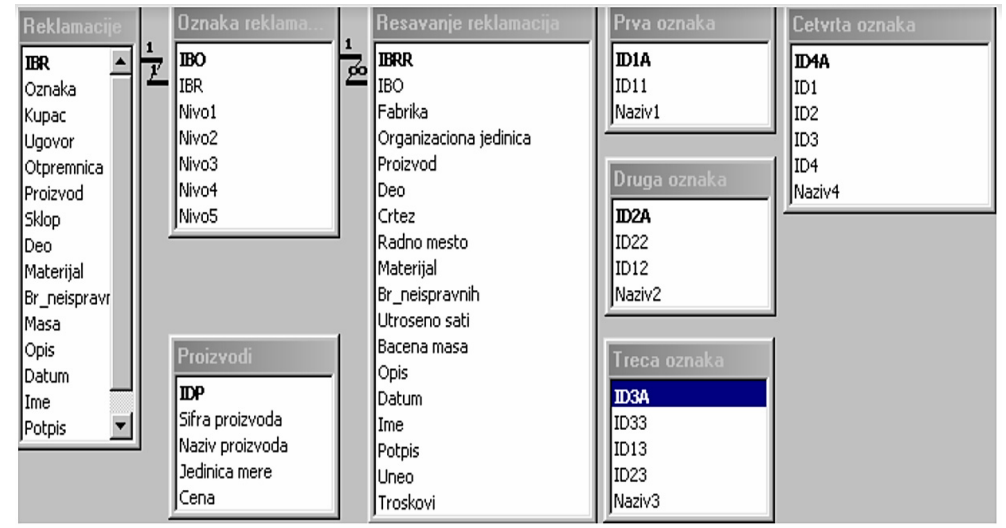

Figure 11 - Example of the window "search for claims on nonconformities” Puc. 11 - Пример окна "поиск претензий по десектам"

Слика 11 - Пример прозора за „претраживање рекламација неисправности”

b) Notification of a complaint includes completing the "Notification of a complaint" form by entering the following: Sequence number, Customer name, Contract number, Dispatch note number, Process output name, Structure, Part and Material of the process output, Number of nonconforming and Mass of process outputs, Description of a complaint, Date of a complaint, Name of the person making a complaint, Signature sign, Identification of a complaint (Level 1-5). Figure 12 shows a window with an example of Notification of a complaint.

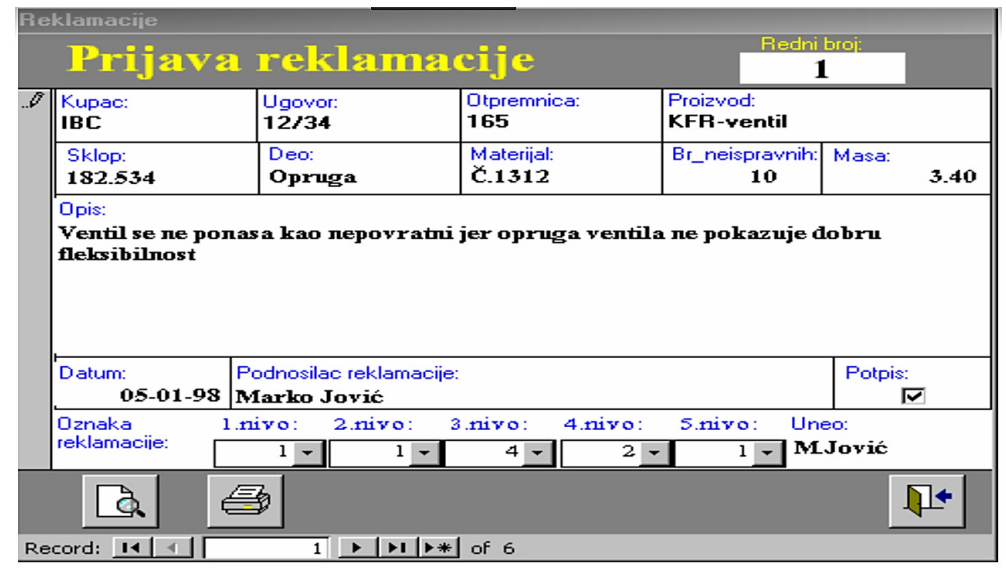

Figure 12 - Example of the window „Notification of complaints“ Pис. 12 - Пример окна "Учет претензий" Слика 12 - Пример прозора „Пријава рекламације” 
c) Processing a complaint is done by organisational wholes (IST, RUK, UPR, PRJ, PLA, OBU, NAB, REA, KON, PRO, UGR, SER) as well as by process output.

d) Resolving a complaint is conducted by: Identification of a complaint, Factory, Organisational unit, Process output, Part of process output, Design, Workplace, Material of process output, Number of nonconforming, Wasted mass, Description of a complaint, Date of sending a complaint, Names and Signatures of claimants and the person that filed a complaint, Costs of the complaint and the Name of the person who resolved the complaint.

e) Preview of resolved complaints by organisational whole as well as by process outputs.

f) Final activation (Print preview and Printing).

\section{Costs of process output nonconformity database (TRO)}

The fifth priority database - Costs of process output nonconformity database (TRO), according to requirements 8.1 and 8.2 .2 of ISO 9001:2015 standard includes planned and incurred costs related to process output nonconformity (semi-products, products, documentation or services).

The fifth priority database - Costs of process output nonconformity database (TRO) includes all planned and incurred costs related to process output nonconformity. It starts from the window "Main Menu" and the "Select the type of equipment" field (Measuring equipment, Testing equipment, Control equipment); such a selection of equipment type enables the following: a) search of already filed data on costs, b) reporting new data on costs, c) preview of diagram charts and d) final activation (Print preview and Printing).

a) The search of already recorded data on costs is conducted by:

I. Organisational wholes (1. Research into market needs (IST), 2. Designing process outputs $\left(P R J_{1}\right), 3$. Development of process outputs $\left(P R J_{2}\right)$, 4. Planning and preparation of execution (PLA), 5. Procurement and storage of materials and equipment $(N A B), 6$. Realisation of technologies (REA), Fitting or installing process outputs (UGR) and Servicing or maintenance of process results (SER), 7. Management and quality assurance of process outputs (UPR) and process output quality control $(K O N)$ and 8. Sales or distribution and storage of process outputs $(P R O)$ ); II. Organisational competences (1. Prototype design, 2. Making of prototype, 3. Inspection of prototype, 4. Prototype storage, 5. Process 
output creation, 6. Delivery, 7. Servicing, etc.); III. Organisational business (1. Processing, 2. Installing, 3. Transport, etc.); IV. Cost caused by (1. Energy, 2. Material, 3. Information); V. Organisational phases (1. Prior to process, 2. During the process, 3. After the process); VI. Organisational processes (1. Shaping, 2. Misshaping, 3. Separation, etc.); VII. Organisational operations (1. Forming from liquid, 2. Forming from pulp, etc.); VIII. Cost elements (1. Raw material, 2 Tools, 3. Auxiliary tool set, 4. Machinery, 5. Management) and IX. Cost caused by (1. Length values, 2. Values of forms, etc.).

b) Notification of new data on costs includes filling in a "Notification of nonconformity costs" form where the following data are entered: Sequence number, Factory name, Organisational whole, Process outputs, Part, Design and Material of process results, Workplace, Number of nonconforming items, Number of hours spent, Amount of recovery costs, Wasted mass of material, Description of costs, Names of the controller and software developer, Signature sign and nine identifications of cost levels $(1,2,3, \ldots, 9)$.

c) Preview of diagram charts is conducted by: Factory name, Organisational whole, Process outputs, Workplace and Part of process output, Number of hours spent, Amount of recovery costs and Wasted mass of material and nine identifications of cost levels $(1,2,3, \ldots, 9)$. Figure 13 presents the window for the preview of costs due to nonconformity at level 1.

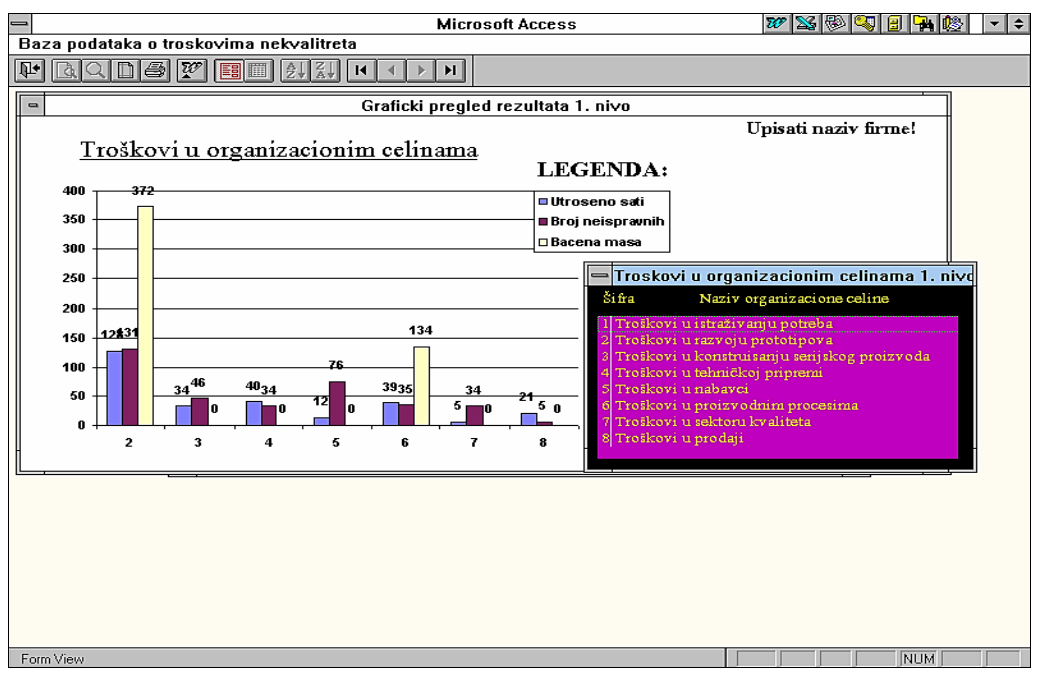

Figure 13 - Example of the window for search of the nonconformities costs at level 1 Puc. 13 - Пример окна для поиска затрат по дефектам на уровне 1

Слика 13 - Пример прозора за прегледање трошкова неисправности на 1. нивоу 
The presented cost values at level 1 demonstrate that they are highest in the second organisational whole (Designing process outputs $\left(P R J_{1}\right)$ due to a wasted mass of $372 \mathrm{~kg}$ of material.

Figure 14 presents the window for the preview of costs incurred by nonconformities at level 2 . These results show that the highest costs are incurred in prototype making (Development of process outputs $\left.\left(P R J_{2}\right)\right)$ due to a wasted mass of $204 \mathrm{~kg}$ of material.

d) Final activation (Print preview and Printing).

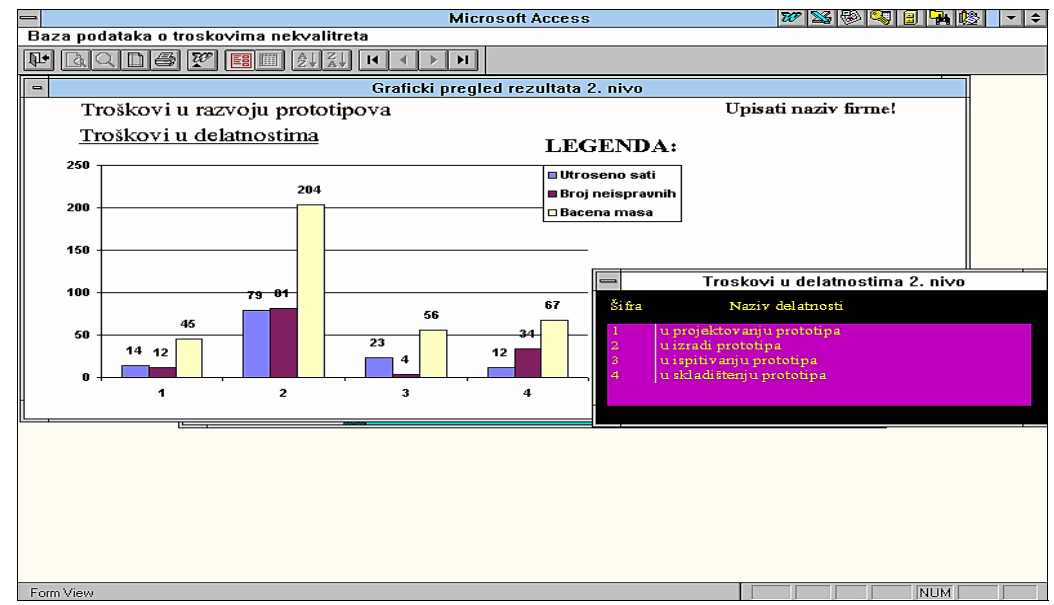

Figure 14 - Example of the window for search of the nonconformities costs at level 2 Puc. 14 - Пример окна для поиска затрат по дефектам на уровне 2

Слика 14 - Пример прозора за прегледање трошкова неисправности на 2. нивоу

\section{Power and work equipment maintenance database} $(O D R)$

The sixth priority database, Power and work equipment maintenance database (ODR), according to requirements 8.5.3 and 7.1.2 of ISO 9001: 2015 standard, includes the organisation's own power equipment (generators, compressors, ventilators, water, water purifiers) and technological equipment (machinery, tools, auxiliary equipment, cranes, transporters) and enables a complete inventory record of equipment and the overall maintenance of equipment. It starts from the window "Main Menu" and the "Power and work equipment" field (Machinery, Tools, Auxiliary equipment, General data); this choice of equipment type enables: a) search of already entered data, b) entry of data on power and work equipment, c) preview of filed equipment and d) final activation. 
a) The search of already recorded data is done by: 1 . Machinery (Records, Maintenance, Maintenance staff), 2. Tools (Records, Maintenance, Maintenance staff), 3. Auxiliary equipment (Records, Maintenance, Maintenance staff) and 4. General data (Classification of machinery according to purpose, Type of machine, Machine group, Classification of machines according to overall dimensions, Classification of machines according to speed of operation, Machine subsystems, Company name). Figure 15 presents the window used to search General data.

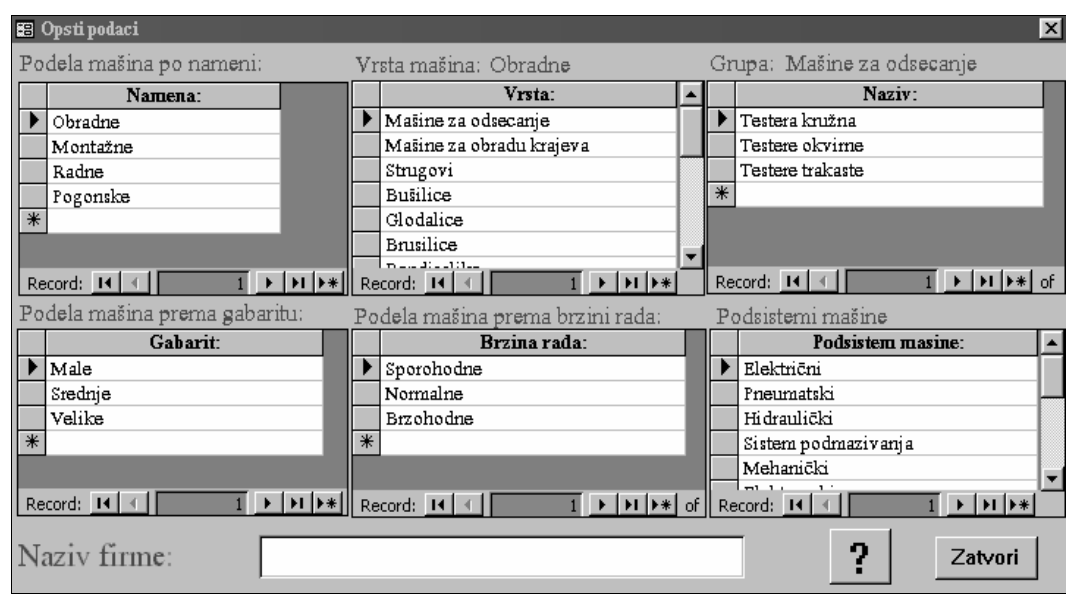

Figure 15 - Example of the window for General data research Puс. 15 - Пример окна для поиска Общих сведений

Слика 15 - Пример прозора за претраживање опитих података

b) Entry of data on power and work equipment involves recording data in the "Equipment record" form, where the following data are filled in: Sequence number, General data on equipment (Photography, outline or scheme of equipment, Name of equipment, Manufacturer, Manufacturer's name of equipment, Type of equipment, Factory number, Year of manufacture, Year of procurement, Work field of equipment, Inventory number, Work position, Group of equipment), Data on the driving power of equipment (Power kW, Voltage V, Electricity A, Frequency of turn $\mathrm{min}^{-1}$ ), Data on parts of equipment (Equipment part name, Part manufacturer, Equipment part type, Power, Frequency of turn), Annexes to equipment (Instructions for use, Schemes, Designs, Electrical scheme, Hydraulic scheme, Lubrication scheme), Review of change in equipment precision (Period, Precision/Accuracy), Data on spare parts (Part name, Product, Type, Identification, Number of pieces, Note), and Data on inspections, 
repairs or overhaul of equipment (Inspection, repair or overhaul, Provider of works, Term, Note).

c) Preview of filed equipment is done by: Data on equipment (Group, Subgroup, Classification according to overall dimensions, Classification according to speed of operation, Manufacturer, Manufacturer's name, Factory number, Year of manufacture, Year of procurement, Work field of equipment, Inventory number, Work position, Identification of working condition), Parts of equipment, Driving power of equipment, Maintenance of equipment (Maintenance staff, spare parts, Machine group), Annexes to equipment, Equipment failures and Change in equipment precision. Figure 16 presents a window with the data on the Universal tool milling machine ALG-200B.

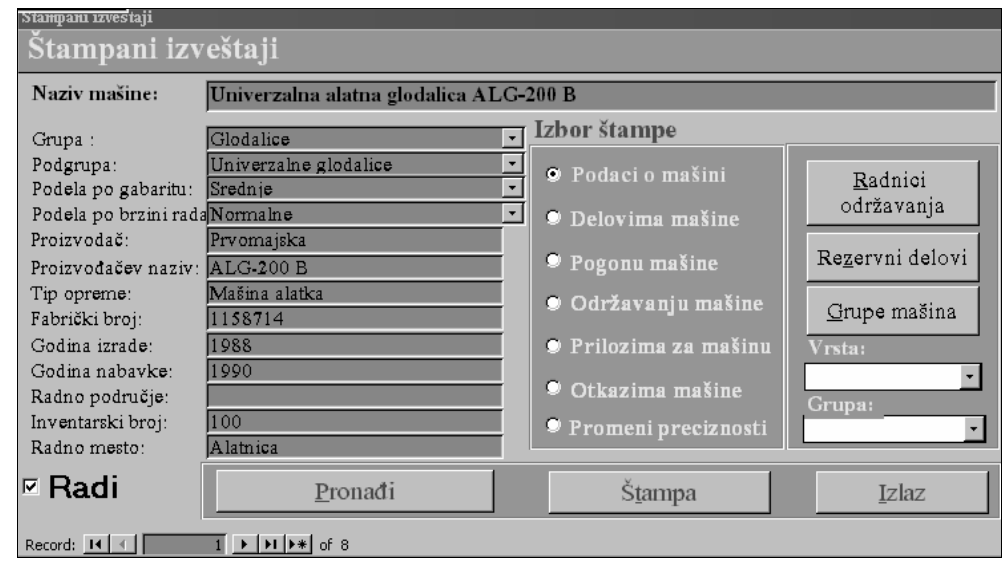

Figure 16 - The window for research of the data for the Universal tool milling machine Puc. 16 - Окно для поиска данных машины Универсальный инструментальный фррезерный станок

Слика 16 - Прозор за прегледање података машине универзалне алатне глодалице

d) Final activation (Print preview and Printing).

\section{Conclusion}

International Quality Management System (QMS) ISO 9001:2015 Standard implemented in this country in business organisations and in public administration comes as a replacement of the previous, ISO 9001:2008 standard. Compared to the previous ISO 9001:2008 standard, this standard does not require a complicated manual to be devised: instead of six, it needs no documented procedures now and only 18 prescribed reports are required in comparison with 21 in the previous 
version. The organisations that have already certified their standards to comply with this earlier standard, ISO 9001: 2008 standard, now have to adopt the new standard of the quality system model, ISO 9001:2015, no later than September 2018. A serious problem in this transition from the earlier to the new standard is the design of necessary databases. For the purpose of successful transition to the new ISO 9001: 2015 standard and an effective quality management system, the authors analysed the required data and information resulting from the requirements of this standard and designed six priority databases that they propose as necessary to implement in manufacturing industry. Using the six priority databases for which conceptual and programme solutions are devised, the organisations that have already certified their quality systems to comply with the earlier standard can make a safe and fast transition to the new ISO 9001: 2015 standard and thus manage quality in an efficient and rational manner even before the given deadline (September 2018).

\section{References}

Armistead, C., \& Machin S., 1997. Implications of business process management for operations management. International Journal of Operations \& Production Management, 17(9), pp.886-898. Available at: http://dx.doi.org/10.1108/01443579710171217.

Chang, K.C., \& Mills, T.M., 2015. Modeling competition over product life cycles,. Asia-Pacific Journal of Operational Research, 32(4). Available at: http://dx.doi.org/10.1142/S0217595915500219.

Day, G., 1981. The product life cycle: Analysis and applications issues. Journal of Marketing, 45, pp.60-67. Available at: http://dx.doi.org/10.2307/1251472.

Đorđević, D.N., 2017. Software quality standards. Vojnotehnički glasnik/Military Technical Courier, 65(1), pp.102-124. Available at: http://dx.doi.org/10.5937/vojtehg65-10668.

- ISO 9000: Quality management system: Fundamentals and vocabulary 2005. Geneva: International organization of standardization.

- ISO 9000: Quality management systems: Fundamentals and vocabulary 2015.

- ISO 9001: Quality management systems: Requirements 2015.

- ISO 9001: Riequirements 2008. Geneva: International organization of standardization.

- ISO/TC 176/SC 2ISO 9004: Managing for the sustained success of an organization: A quality management approach 2009.

- ISO/TC 176/SC 3ISO 10002: Quality management: Customer satisfaction: Guidelines for complaints handling in organizations 2014. 
- ISO/TC 176/SC 3ISO 10004: Quality management: Customer satisfaction: Guidelines for monitoring and measuring 2012.

- ISO/TC 176/SC 3ISO/NP 10015: Quality management: Guidelines for competence management and training.

- ISO/TS 9002: Quality management systems: Guidelines for the application of ISO 9001: 20152016.

Miletić, Lj., 2001a. Organizovanje, projektovanje i uvođenje potrebnih baza podataka za sistem kvaliteta u preduzećima metalske industrije (in Serbian), Ph.D. thesis, University of Belgrade, Faculty of Mechanical Engineering.

Miletić, Lj., 2001b. Projektovanje baze podataka „Troškovi" (in Serbian). Tehnika, 56(6), pp.7SK-10SK6.

Miletić, Lj., 2001c. Projektovanje baze podataka MIK za sistem kvaliteta (in Serbian). In: III Međunarodni simpozijum SIE Industrijsko inženjerstvo, Beograd.

Pavlović, Z.B., \& Karović M.S., The application of bass difusion model in forecasting telecommunication services users in military assistance to civilian authorities. Defence Science Journal, 65(2), pp.144-149. Available at: http://dx.doi.org/10.14429/dsj.65.6026.

Popović, B., 1993. Ulazna kontrola u sistemu kvaliteta (in Serbian), Beograd: Nauka.

Popović, B., 2002. Procesna kontrola u sistemu kvaliteta (in Serbian). Beograd: Nauka.

Popović, B., 2014. Sistem šest sigma u usluživanju rezultatima procesa (in Serbian). Beograd: Akademska misao.

Popović, B., \& Todorović, Z., 1998. Obezbeđenje kvaliteta (in Serbian). Beograd: Nauka.

Popović, B., \& Todorović, Z., 2000. Izlazna kontrola u sistemu kvaliteta (in Serbian). Beograd: Nauka.

Sroufe, R., \& Curkovic, S., 2008. An examination of ISO 9000:2000 and supply chain quality assurance. Journal of Operations Management, 26(4), pp.503-520. Available at: http://dx.doi.org/10.1016/j.jom.2007.06.006.

Vanhaverbeke, W., \& Torremans H., 1999. Organizational structure in process-based organizations. Knowledge and Process Management, 6(1), pp.41-52. Available at: http://dx.doi.org/10.1002/(SICl)10991441(199903)6:1<41::AID-KPM47>3.0.CO;2-4.

Miletich, L., \& Rychkova M., 2010. Proektirovanie baz dannyh «Zhaloby» po Sisteme kachestva / Planning data base "Complaints" for Sustem Quality (in Russian). Надёжность и качество (Nadezhnost' and Kachestvo), 1, pp.8-10.

ПРОЕКТИРОВАНИЕ ПРИОРИТЕТНЫХ БАЗ ДАННЫХ ДЛЯ СИСТЕМЫ МЕНЕДЖМЕНТА КАЧЕСТВА (QMS), В СООТВЕТСТВИИ С ИСО 9001: 2015

Лиляна 3. Милетич, Аца Д. Йованович, Филипп П. Йованович, Весна В. Буха

Университет EDUCONS в г.Сремская Каменица, Факультет Управления инновационными проектами, г.Белград, Республика Сербия 
ОБЛАСТЬ: компьютерные науки, информатика, управление качеством ВИД СТАТЬИ: обзорная статья ЯЗЫК СТАТЬИ: английский

Резюме:

Международный стандарт системы менеджемента качества ISO 9001: 2015 в Сербии имеет весьма широкое применение, особенно в коммерческих организациях и в государственном управлении. Стандарт был разработан в 1987 году а первые изменения были внесены в 1994 году, а затем в 2000-ом и 2008--ом годах, объем изменений с каждым разом увеличивался, упрощая документооборот при его внедрении Так, например, по сравнению с предыдущим стандартом ISO 9001: 2008, последний стандарт не требует сложных Регламентов, вместо шести, теперь вовсе не требуется проведение документированной процедуры и вместо 21-го теперь достаточно подготовить 18 предписанных отчетов. Организации, которые уже сертифицированы на соответствие с предыдущим стандартом ISO 9001: 2008 должны перейти к новому стандарту до сентября 2018-го года. Одной из основных проблем в этом переходе является создание необходимых баз данных, которые необходимы для практического применения нового стандарта. Авторы статьи в качестве решения этой проблемы, предлагают общую модель, состоящую из шести приоритетных баз данных: База данных по документообороту; База данных по измерительному, контрольному и испытательному оборудованию; База данных по персоналу; База данных по претензиям на дефекты; База данных по затратам на дефекты; и База данных по эксплуатации и техническому обслуживанию рабочего оборудования.

Ключевые слова: приоритетные базы данных, система управления качеством, стандарт ISO 9001: 2015.

\section{ПРОЈЕКТОВАњЕ ПРИОРИТЕТНИХ БАЗА ПОДАТАКА ЗА QМS НА ОСНОВУ СТАНДАРДА ISO 9001:2015}

Љиљана З. Милетић, Аца Д. Јовановић, Филип П. Јовановић, Весна В. Буха

Универзитет EDUCONS у Сремској Каменици, Факултет за пројектни и иновациони менаџмент, Београд, Република Србија

ОБЛАСТ: рачунарске науке, информатика, управљање квалитетом ВРСТА ЧЛАНКА: прегледни чланак ЈЕЗИК ЧЛАНКА: енглескИ 


\section{Сажетак}

Међународни стандард за Систем управљања квалитетом ISO 9001:2015 има у нас веома широку примену, нарочито у привредним организацијама и јавној управи. Стандард је настао 1987, а ревидиран је 1994, 2000. и 2008. године, сваки пут уз све веће измене, а последњи пут и уз највеће промене. У односу на претходни стандард ISO 9001:2008, овај стандард не захтева израду компликованог приручника, уместо шест сада није потребан ниједан документовани поступак, а уместо 21 сада је довољно 18 прописаних извештаја. Организације које су већ цертификовале своје системе према ранијем стандарду ISO 9001:2008 сада морају да пређу на нови стандард, најкасније до септембра 2018. године. Један од већих проблема у овом преласку представља израда потребних база података које су неопходне за практичну примену новог стандарда. Као решење овог проблема аутори предлажу генерални модел са шест приоритетних база података: база за документоване информације; база за мерну, контролну и испитну опрему; база за стручне кадрове; база за рекламације неисправности резултата процеса; база за трошкове неисправности резултата прочеса и база за одржавање погонске и радне опреме.

Кључне речи: приоритетне базе података, систем управљања квалитетом, стандард ISO 9001:2015.

Paper received on / Дата получения работы / Датум пријема чланка: 16.12.2016. Manuscript corrections submitted on / Дата получения исправленной версии работы / Датум достављања исправки рукописа: 24.01.2017.

Paper accepted for publishing on / Дата окончательного согласования работы / Датум коначног прихватања чланка за објављивање: 26.01.2017.

(C) 2017 The Authors. Published by Vojnotehnički glasnik / Military Technical Courier (www.vtg.mod.gov.rs, втг.мо.упр.срб). This article is an open access article distributed under the terms and conditions of the Creative Commons Attribution license (http://creativecommons.org/licenses/by/3.0/rs/)

() 2017 Авторы. Опубликовано в «Военно-технический вестник / Vojnotehnički glasnik / Military Technical Courier» (www.vtg.mod.gov.rs, втг.мо.упр.срб). Данная статья в открытом доступе и распространяется в соответствии с лицензией «Creative Commons» (http://creativecommons.org/licenses/by/3.0/rs/)

() 2017 Аутори. Објавио Војнотехнички гласник / Vojnotehnički glasnik / Military Technical Courier (www.vtg.mod.gov.rs, втг.мо.упр.срб). Ово је чланак отвореног приступа и дистрибуира се у складу са Creative Commons licencom (http://creativecommons.org/licenses/by/3.0/rs/).

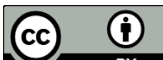

